\title{
REVIEW I Jazz as Visual Language: Film, Television and the Dissonant Image
}

Nicolas Pillai

London: I.B. Taurus, 2017

ISBN: $9781784533441(\mathrm{HB})$

\author{
Alyn Shipton \\ Royal Academy of Music \\ AShipton@ram.ac.uk
}

At the heart of this study is the idea of the "dissonant image". Despite a paragraph or two attempting to place this notion in a smorgasbord of critical stances, in his introductory section the author is somewhat unsuccessful in conveying what his central concept actually is, at least with sufficient clarity and certainty to direct the reader forth into the three case studies on jazz films or television shows that form the heart of the book. Using a musical term - dissonance, that is a mingling of discordant sounds - to convey non-musical ideas, which, although he never specifically defines it, tends to be applied in the more widely used general sense of a lack of agreement (16), may be unhelpful in a book that is at least in some respects about music.

The question is whether there are "wrong notes" in jazz as Ajay Heble (quoted) and Pillai suggest. There is certainly a generation of jazz musicians and improvisers who would say that there is no such thing as a wrong note and who - even if they admitted the concept - might find it risible that such a note "can be a politically and culturally salient act for oppressed groups seeking alternative models of knowledge production and identity formation" (12). Pillai then suggests that on screen "jazz is in constant dialogic exchange with its framing medium" (13), but that is as true of ballet, opera, Broadway musicals, or any other genre of music performance treated in film, and the point he makes about this being critical to the "tone and cultural positioning" (13) of jazz would apply to them, or indeed to such non-musical forms as the novel, the epic poem, or the stage play. The lack of inclusion - awareness even - of a wider context, both beyond jazz and within it, is one of the more problematic elements of this book.

What we ultimately arrive at is the idea that "dissonance" (16) is a metaphor "which might extend our understanding of language in both filmic, televisual and jazz contexts" (16). So, we learn that Pillai's stance is to explore "a lack of 
agreement" (16) between jazz and the ways in which it is presented on screen, and that he intends to use the "radical attack" (16) and "generative possibilities" (16) of this to understand ways in which film and TV understand and transform jazz.

Before arriving at the main case studies there is a diversion into the 1957 television programme The Sound of Jazz. This is a helpful assemblage of written recollection, but again tends to sidestep any wider context. We have Nat Hentoff and Whitney Balliett's memories of the show, proposing that it used "cameramen who could improvise" (19). But there is no mention of the full-length rehearsal (issued on CD, so there is no mystery about it), which presumably allowed this "improvisation" by the cameras to be rehearsed. We rush into a discussion of mythmaking and the theory of the close up, while by-passing an aside devoted to the "degrading construction" (20) of Benny Carter's observation that seeing musicians in hats and smoking was "an insult". Here there is an iconographic opportunity missed to explore the distinction between the way Carter (a distinguished big-band player and arranger, conditioned to the ethos of smart suits and ties) believed jazz ought to be presented on screen, and producer Robert Herridge's attempt to depict the attire and attitudes documented in many a still shot of an informal audio studio recording (some of the same musicians, for example, appearing fully hatted and some of them puffing away, in photos of Juanita Hall's 1957 sessions or - a few years earlier, and crying out for a cross reference to the second case study - Gjon Mili's photos of Sarah Vaughan with J.C. Heard's band for Life magazine).

The meat of the book is its case studies, of which the first is somewhat tangential to jazz, the second central to the idea of the Hollywood short, and the third a really impressive and in-depth study of the BBC's Jazz 625 series.

The first looks at Len Lye's film A Colour Box. Much of it (though maybe less than Pillai surmises) was drawn onto celluloid, making it a direct film. We learn little of the editing process, or how titles were superimposed on his drawn images - were these segments perhaps more conventional animation cels? The soundtrack is a pre-existing beguine by Don Barretto, which might not exactly be regarded as jazz, and Pillai suggests that (following Luke Smythe's analysis) the film "inverts conventional synchronization practice in that the soundtrack was recorded ahead of the visuals" (36). This may be true of live action films, where post-production saw dialogue dubbed and music recorded, but animations were invariably produced to pre-existent soundtracks. Whatever method was made to produce the film, where does it stand in terms of jazz and animation? Fischinger's equally abstract 1938 film An Optical Poem (made, not in Europe as Pillai suggests, but in the USA for MGM) uses classical music to create a very similar set of images, albeit produced from stop motion, but does the use of Liszt's Hungarian Rhapsody place it outside the "popular discourse" (33)? This was only two years before Disney's Fantasia which one might argue placed classical music firmly at the centre of popular discourse.

And mention of Disney makes one wonder as to Pillai's choice of Lye's marginal film. If one is actually going to look at Jazz as Visual Language in 1930s animation, might it not have been more effective to look at, say, the Silly Symphony: The Land of Jazz (1935), which shows the Disney studios' take on both jazz and classical music. Or, in terms of improvisational technique, to look back at 1931 and the Fleischer brothers' use of the Rotoscope, where Cab Calloway's dancing was used as the basis for their Betty Boop animations?

The Gjon Mili film Jammin' The Blues is the next case study. Here again, the lack of context makes some of the chapter's assumptions questionable. If it has a direct precedent, it is Lew Grade's 1938 film Jazz 'Hot', made in London to promote the first UK tour by the Quintet of the Hot Club of France. A similar (though more 
extended) narration precedes the heart of the film, and a very similar monochrome sequence illustrates the Quintet playing "J'Attendrai", where (again filmed to a preexistent soundtrack) the musicians alter their positions between shots, notably the placing of Django Reinhardt himself.

Mili's journey from still photographer to film director is traced autobiographically, but the visual tropes of his studio stills did not come out of nowhere. His 1943 Life magazine jam session assignment, which Pillai presents as a prequel to the film, had been prefigured by Chuck Peterson for the same magazine in 1939, and the visual language is strikingly similar. And equally, many of the images in Jammin' The Blues itself adapt ideas from the contemporaneous still photography of Bill Gottlieb, so for example the close ups of Red Callendar's bass are prefigured in Gottlieb's late 1930s portraits of Slam Stewart, or fractured multiple images are used in his pictures of the drummer Ray McKinley.

Pillai then suggests that this film was a "soundie" (66), a quite separate genre of film, made to run on the Mills Panorama, which was a kind of visual jukebox, and he conflates discussion of genuine short movies for cinematic distribution with these single-song low-budget films aimed at bars and cafés. The point he makes about soundies as typifying "the retreat into dream space which nevertheless provided commentary on the role of jazz musicians in wider society" (67) might more aptly have been applied to the two full-length Hollywood movies of the previous year, Cabin in the Sky and Stormy Weather, which featured all African American casts (the studio system having eschewed the Office of War Information and NAACP's drive to produce racially integrated films). More worryingly, he then turns to a discussion of bebop subculture. In 1944 when this film was shot in Hollywood, bebop was barely on musicians' radar, and the Parker and Gillespie sextet would not bring the mature form of the music (as yet unrecorded owing to the AFM recording ban) to the West Coast until the final month of the following year, and even the earlier pioneering group of Coleman Hawkins and Howard McGhee did not arrive in California until the spring of 1945. Not one of the musicians in Jammin' The Blues had anything to do with bebop, then or subsequently, so this is a complete red herring.

Fortunately, the final study on Jazz 625 is excellent, and might easily have been expanded into a full book in its own right on 1960s jazz and the BBC. Backed up by a full table of transmissions, and with intriguing and fascinating discussion of everything from studio technique to the aesthetic strategies of the programme, it picks a sensitive and delicate path through critical writing on the subject and explores the ground-breaking series in real depth. For this alone, the book is very valuable, and it would be good to see this discussion placed in the context of earlier American series such as Art Ford's Jazz Party (WNTA TV, 1958). Maybe more tellingly, Jazz 625 might be compared to what the BBC was attempting in Top of the Pops which began transmission three months earlier in 1964, and which tied its mimed visuals to pre-recorded soundtracks, the antithesis of Pillai's excellent point that Jazz 625 adopted aural conventions "dictated more by radio than by film" (102). There is more work to be done here, but this chapter shows that the ground is well-prepared.

\section{Filmography}

A Colour Box, 1935. Dir. Len Lye, GPO Film Unit.

An Optical Poem, 1938. Dir. Oskar Fischinger, MGM.

Art Ford's Jazz Party, 1958. WNTA TV, NY, transmission 8 May- 25 Dec 1958. 
Cabin in the Sky, 1943. Dir. Vincente Minelli, MGM.

Fantasia, 1940. Dir. Walt Disney and Ben Sharpsteen, Walt Disney Productions.

Jammin' the Blues, 1944. Dir. Gjon Mili, Warner Bros.

Jazz 625, BBC 2, transmission 22 Apr. 1964 -13 Oct. 1966

Jazz 'Hot', 1938. Dir. Lew Grade, production company uncredited.

Minnie The Moocher, 1932. Dir. Max Fleischer, Talkartoon.

Silly Symphony: The Land of Jazz (Music Land), 1935. Dir. Wilfrid Jackson, Walt Disney

Productions.

Stormy Weather, 1943. Dir. Andrew L. Stone, 20 ${ }^{\text {th }}$ Century Fox.

The Sound of Jazz, 1957. Dir. Jack Smight, CBS.

Top of the Pops, 1964. BBC 1, transmission from 1 Jan. 